\title{
The Evolving Roles of Landscaping in Campus Space Management: Ekiti State University, Ado-Ekiti, Nigeria in Focus
}

\author{
Olanibi Julius Adekunle, Joseph Omoniyi Basorun \\ Department of Urban and Regional Planning, Federal University of Technology Akure, Nigeria \\ Email: olanibijulius@gmail.com,nbason2003@yahoo.com
}

How to cite this paper: Adekunle, O.J. and Basorun, J.O. (2016) The Evolving Roles of Landscaping in Campus Space Management: Ekiti State University, Ado-Ekiti, Nigeria in Focus. Journal of Environmental Protection, 7, 1380-1388.

http://dx.doi.org/10.4236/jep.2016.710119

Received: February 16, 2016

Accepted: September 25, 2016

Published: September 29, 2016

Copyright $\odot 2016$ by authors and Scientific Research Publishing Inc. This work is licensed under the Creative Commons Attribution International License (CC BY 4.0).

http://creativecommons.org/licenses/by/4.0/

\begin{abstract}
The aesthetic quality of most of the universities' campus environment in Nigeria deserves attention considering the inadequate, misused and mismanagement of the campuses' open spaces. This has exerted a major strain on the welfare and productivity of people (staff and students) in the universities. This study identifies the evolving positive roles of landscape in campus space management with a particular reference to the Ekiti State University, Ado-Ekiti, Nigeria. Random sampling method was adopted to collect data and information from the students, staff and heads of Planning and Horticulture Units of the institution. The results show that, challenges facing landscape planning in the university include inadequate finance, inadequate facilities, management problem and attitudinal problem of landscape users. The study recommends proper use and management of open space, landscape elements, outdoor rooms with various spatial qualities, and provision of enough funds to Planning and Horticulture units for landscape planning and environmental improvements.
\end{abstract}

\section{Keywords}

Ado-Ekiti, Campus, Landscape, Space Management, University

\section{Introduction}

Landscape is the art of designing, planning and management of land, arrangement of natural and man-made elements there on, through application of cultural and scientific knowledge with concern for resources conservation so that the resultant environment can serve a useful, healthy and enjoyable purpose [1]. It deals with the beautification and management of the environment by the organization of spaces with adequate cog- 
nizance of the basic principles of design. Landscaping is an integral part of our culture and plays an essential role in the quality of our environment, economic wellbeing of the people, as well as their physical and psychological health. Smith believes that it is a way of maintaining and enhancing the quality of human life by protecting the health of the biosphere and husbanding the key resources of the air, water, land and minerals [2].

Landscape is one of the most cost effective tools for improving and sustaining the quality of the environment whether in the school environment, the city, the suburbs or the country [3]. Through our garden and landscapes, we acquire a personal awareness and responsibilities for the environment while we relieve the tensions and frustrations of everyday life. As rightly observed, environmental sustainability programs attempt to reduce the use of physical and renewable resources, rather than toxic materials, the protection and restoration of natural habitats and environmental values for their livability or beauty [2].

Many great campuses are defined by the strength of their landscapes and open spaces, and depend on these assets as a means of attracting students. Landscape planning is a creative conservation with the purpose of reconciling competing land uses without destroying the natural and cultural resources with which societies are recognized; making the best use for mankind of the acquired space while conserving its beauty and fertility. The role of landscape design and planning in the improvement and sustainability of the existing universities' open spaces is fundamental, in establishing a working relationship between landscaping and open space management. However, Falade stresses the need for adequate knowledge of the concept of open spaces and its super imposition nature on other concepts such as garden, parks, and landscaping generally [4].

The campus open spaces and public realm play an important role in defining the University and in creating memorable first impressions of the campus environment and experience. The open spaces and streetscapes on the campus should represent landmark status that constitutes attractive spaces that represent campus identity, reflect the quality of the campus environment, and draw attention to the campus as a unique and distinct institution. With careful consideration of the campus design, functionality, and materials, a lasting and memorable experience of the campus' public realm is established.

The entire campus environment becomes a landmark space with the gateways, and associated academic, residential, commercial and celebratory uses. The overall landscaping, hence, reinforces the vision of the campus in its park setting, and defines the character of the various open spaces. This paper, therefore, advocates the evolving roles of landscape in campus space management, with a view to sustaining the Ekiti State University's campus environment. The objectives of the study are to: 1) examine the existing landscape pattern of the University; 2) investigate the activities of the Planning and Horticulture units of the institution; 3 ) assess the quality of opens space management therein; and 4) examine the level at which sustainable campus environment is achieved with the present landscape. 


\section{Literature Search}

Nuttgens defines the term landscape in its widest sense and equated it with the environment which is literally our surrounding [5]. Landscape evolves as a result of interaction between man (as an individual) and "non-human" (as a set of process or a store house of materials). It is the back-cloth against which we can measure the importance of our activities and the scale of our personalities. There is a clear distinction between landscape planning and landscape design. Landscape planning is likened to environmental planning which embraces a broad field of activities within the ambit of the outdoor scene and other components of man's environment [6]. It is a process concerned with activities geared toward the articulation of existing open space for the purpose of enhancing the quality of the environment [7]. Landscape design on the other hand, is defined primarily as a fine art whose most important function is to create and preserve beauty in the surroundings of human habitations and broader natural scenery of the country [8].

The enormous and the accelerating expansion of the technological development of human race have produced a corresponding expansion in the humanization, urbanization and the sterilization of the landscape. This has aggravated the misuse of land resources, haphazard urban development, piece meal and uncharted rural development. Fadamiro opines that the objective of landscaping is to consider the entire landscape as experienced by individual human beings, and general design processes as key issues which are applied to specific projects like gardens, parks and cities [9]. Professions like planning, engineering, architecture and landscape architecture are most directly involved in the design of landscape, in which graphic design, object design, industrial design, painting and sculpture play important roles.

Mitchell identified three basic types of landscape, viz: Primary, natural and cultural landscapes. Primary landscape occurs from the purely natural factors without human interference [10]. The natural landscape is a creation that emanates from the first stage of transformation of the natural environment by human interference. The cultural landscape becomes obvious when the changes introduced by human activities are so deep and basically involve maintenance of the newly attained stability only by constant interference of man. Two main types of culturallandscapes exist. These include; harmonious landscape which occurs when the landscape is adopted and fits well into the character of the natural environment and the degraded cultural landscape which occurs when man, after using its new economic activities looks for excessive benefits, thus, causing the permanent and progressive growth of desirable changes in the natural environment [10].

The elements of importance in landscaping include plant materials, such as trees, shrubs, ground covers and grasses [11]. They are used in different areas for design according to their required functions like accent, softening, screening, framing and shading. Man-made structural materials are used for enclosure, surfacing and transmission or circulation within and between spaces provided. However, the essential principles for their effective use include the knowledge of the inherent characteristic and proper- 
ties of the materials. Invariably, landscape elements are all forms of planting and vegetation, adjustments, refinements or designed developments in ground forms, rock groupings and water patterns; all constructions excluding completely enclosed buildings or primary institution, engineering structures such as walks, terraces, steps, walls, screens, shelters, play area, and so on [12]. These are the elements used to develop and refine spaces between, around, or within buildings and vehicular routes when they occur either intentionally or accidentally.

Hard landscapes are the inorganic materials which are inert in nature (stationary) and the synthetic elements of space. These include the roads, buildings, paths, wall fences, paved areas, sculptures and statues, engineering bricks, metals, carvings, glass and plastics. Others include paving, wall steps, ramps, sculpture; out-door lightening and road furniture-benches. Soft landscape refers to the living or natural materials used in landscaping. These include vegetation, plant materials (grasses, screens and hedges and trees) and water bodied including artificial falls, ponds, lakes, pool and fountains [13]. The use of line, focal point or emphasis, simplicity, form, texture, color, balance, repetition, variety, grouping, mass, scale and proportion, rhythm, sequence and scale are the basic principles of landscape design to be applied to organize landscape space [14]. Above all, there are five keys to effective space management as far as college (institution) campuses are concerned which include: Improvement of space utilization, increase in scale of campus buildings, optimizing the mix and flexibility of space, coordination of repairs and modernization as well as addition by removal [15].

Diane [3] argues that a well-designed landscape will help in the reduction of soil erosion, global warming, conservation of natural resources, and pollution prevention. This is because plants and trees used for landscaping can absorb carbon (IV) oxide from the atmosphere (major contributor to global warming), improve air quality and screen busy streets from traffic noise. The assertion of Environmental Protection Agency (EPA) is that urban forests reduce urban air temperatures significantly by shading buildings and concrete and returning humidity to the air through evaporation and cooling. Trees shading homes can reduce attic temperatures to as much as 40 degrees. Generally, the sun, wind, surrounding landforms and landscaping interact with each other to determine the microclimate of an environment.

\section{The Study Area}

Ekiti State University (EKSU) Ado-Ekiti is sited in Ado-Ekiti, the capital city of Ekiti State, Nigeria. Ado-Ekiti is located on latitude $7^{\circ} 37^{\prime} 15^{\prime \prime} \mathrm{N}$ and Longitude $5^{\circ} 13^{\prime} 17^{\prime \prime} \mathrm{E}$. The University is located at kilometer 5 along Ado Ifaki road, Ado-Ekiti in Western Nigeria. At inception in 1982 it was named Obafemi Awolowo University (OAU). The name was changed to Ondo State University in 1985, in November 1999, it was renamed University of Ado-Ekiti (UNAD) and recently changed to its present name Ekiti State University, Ado-Ekiti. Besides the College of Medicine, there are eight other faculties: Arts, Sciences, Agricultural Sciences, Management Sciences, Engineering, Education, Law, and Social Sciences. The University has residential and sports facilities for staff 
and students on campus. Currently, it has about 25,000 students' population and about 70 staff members of the Planning and Horticulture Units of the University.

\section{Research Methods}

The target population for this research includes students, staff and the heads of the Planning and Horticulture Units (PHU) of the University. There are about 25,000 students in the study area, 30 students and 20 staff members were taken as samples from each of the eight faculties which summed up to 240 and 160 respectively. Two (2) heads of the Planning and Horticulture Units were also interviewed, making a total of 402 samples considered for the study. Essentially, the sources of data for this research were both primary and secondary. The primary data were obtained through personal observation and the administration of multiple-choice questionnaires randomly on the students and staff. The selection of the students was based on their availability while the selection of the staff was based on their knowledge of the subject matter. The secondary data were obtained from textbooks, project dissertations, seminar papers, journals and research materials on campus landscape. Simple descriptive statistics was used in data analysis. Tables and charts were employed to present the magnitude of occurrences of the variables that were obtained.

\section{Discussion and Findings}

\subsection{Staff Qualification}

It was revealed that majority (63.3\%) of staff of the Planning and Horticulture Unit are at most secondary school certificate holders and unskilled who help in maintaining the landscape elements in the University (Figure 1). As the dominant workforce, their low qualification and non-specialization in landscape planning and design is likely to affect the landscaping of the campus.

\subsection{Landscape Perception}

The conceptions of the staff and students of the University on sustainability of the campus environment through landscape vary widely. Majority of them (62.2\%) strongly

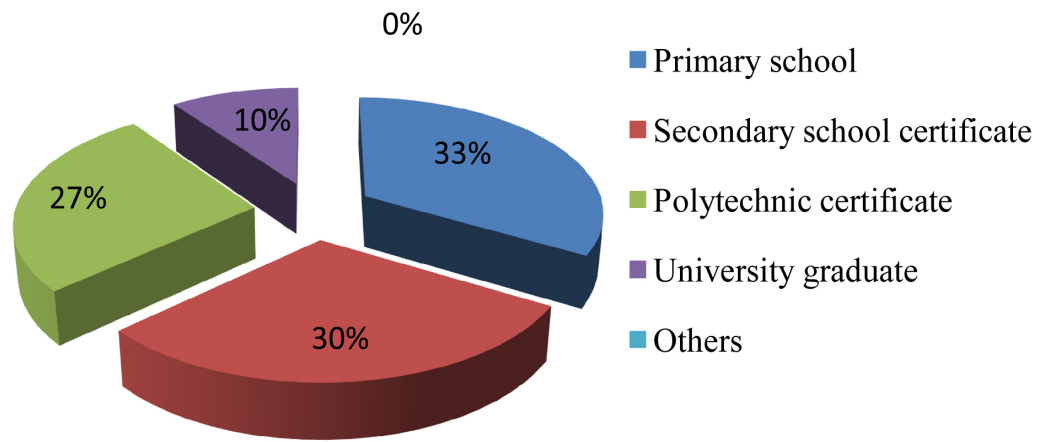

Figure 1. Qualification of staff of Planning/Horticulture units EKSU. Source: Field survey, 2015. 
agree that, a campus environment can be sustained through landscape, just as $63.7 \%$ opined that lack of maintenance culture followed by ignorance of the importance of landscape $(28.6 \%)$ are the major problems influencing the landscape quality of the University as reflected in Table 1 and Plate 1 (Table 2). This is consistent with the views of Forbes and Kindle that, landscape should be properly maintained to sustain its quality [16]. Further investigation revealed that both natural and man-made landscape materials are actually required for this purpose (Table 3 ) so that the significant role of landscape will be achieved in the University. According to the respondents the major roles include: reduction of erosion (22.3\%), wind breaking (20.3\%), aesthetic (25.0\%) conservation of natural resources (10.7\%), reduction of global warming (10.3\%) and improvement of air quality $(10.0 \%)$.

Table 1. Sustaining the campus environment through landscape (students and staff).

\begin{tabular}{cccccc}
\hline Respondents & $\begin{array}{c}\text { Strongly } \\
\text { Agreed }\end{array}$ & Agreed & $\begin{array}{c}\text { Strongly } \\
\text { Disagreed }\end{array}$ & Disagreed & Total \\
\hline Students & 135 & 72 & 10 & 23 & 240 \\
Staff Members & 113 & 41 & 4 & 2 & 160 \\
Staff PHU & 2 & - & - & - & 2 \\
Total & 250 & 113 & 14 & $6.2 \%$ & $100 \%$ \\
$\%$ & $62.2 \%$ & $28.1 \%$ & $3.5 \%$ & & \\
\hline
\end{tabular}

Source: Field survey, 2015.

Table 2. Problems influencing the quality of landscape.

\begin{tabular}{ccccccc}
\hline Respondents & $\begin{array}{c}\text { Lack of } \\
\text { Maintenance }\end{array}$ & $\begin{array}{c}\text { Bush } \\
\text { Burning }\end{array}$ & Pollution & $\begin{array}{c}\text { Soil } \\
\text { Erosion }\end{array}$ & $\begin{array}{c}\text { Ignorance of } \\
\text { Users }\end{array}$ & Total \\
\hline $\begin{array}{c}\text { Students } \\
\text { Staff }\end{array}$ & 157 & - & 1 & 24 & 58 & 240 \\
Members & 98 & - & 2 & 3 & 57 & 160 \\
Staff PHU & 2 & - & - & - & - & 2 \\
Total & 257 & - & 3 & 27 & 115 & 402 \\
$\%$ & $63.7 \%$ & & $0.7 \%$ & $6.7 \%$ & $28.6 \%$ & $100 \%$ \\
\hline
\end{tabular}

Source: Field survey, 2015.

Table 3. Landscape materials needed for campus beautification.

\begin{tabular}{ccccccc}
\hline Respondents & $\begin{array}{c}\text { Plant } \\
\text { Materials }\end{array}$ & $\begin{array}{c}\text { Structural } \\
\text { Materials }\end{array}$ & $\begin{array}{c}\text { Natural } \\
\text { Elements }\end{array}$ & Man-made & $\begin{array}{c}\text { Natural and } \\
\text { Man made }\end{array}$ & Total \\
\hline Students & 68 & 33 & 11 & 40 & 88 & 240 \\
Staff & 41 & 12 & 11 & 31 & 65 & 160 \\
Staff PHU & 1 & - & - & - & 1 & 2 \\
Total & 110 & 45 & 22 & 71 & 154 & 402 \\
$\%$ & $27.4 \%$ & $11.1 \%$ & $5.5 \%$ & $17.7 \%$ & $38.3 \%$ & $100 \%$ \\
\hline
\end{tabular}

Source: Field Survey, 2015. 


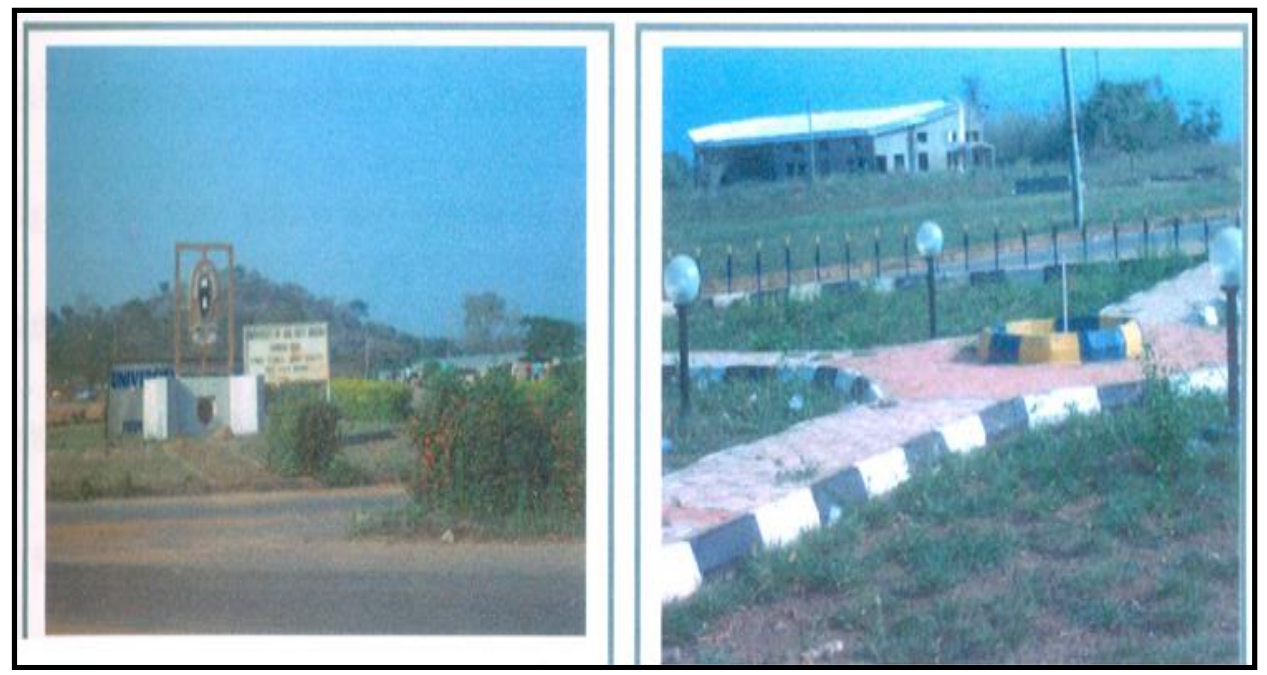

Plate 1. Existing landscape pattern of EKSU.

\subsection{Landscape and Campus Microclimate Control}

Control of microclimate within the campus can be achieved with the use of soft and hard landscape elements. Soft landscaping describes plant materials such as new lawn created by seeding or turfing, planted borders, shrubbery and trees while the hard landscaping elements are "all wide range of hard materials like bricks, gravel, rocks or stone, concrete, timber and other elements including simple structure, steps, paving, garden furniture, wall and fences used by designers to develop landscape design" [17].

Trees in landscape serve the purpose of creating shades (Plate 2), aesthetics as well as improving air quality and representing buffers between pedestrians and traffic. The use of trees and shrubs is highly significant in the provision of shades and control of relative humidity and air movement. They contribute more in the attainment of thermal comfort than any other elements. Tree leaves are arranged to catch as much of the sun ray as possible, thus providing the best possible shade which is far superior to that provided by the roof or wall. Most of the plants and shrubs found on the University site are native to the local environment [18]. Tree and shrubs, no doubt, add beauty and values to buildings and the totality of the environment. They help modify the microclimate around buildings and outdoor living environment. In landscaping, however, correct plants selection, proper timing of plants and plantings techniques are vital to achieving success in creating a scenic environment. Essentially, the selection of plants should be based on the functional roles they will play in the overall landscape [19].

\section{Conclusion and Recommendation}

The need for man to live and work in a good quality, functionally efficient and an aesthetic environment calls for landscape design and planning. Open spaces need to be well planned, managed, organized and maintained. Professionals in landscape planning and other related disciplines (Horticulturists, landscape planners and so on) should be employed in the Planning and Horticulture unit to handle issues of landscape design 

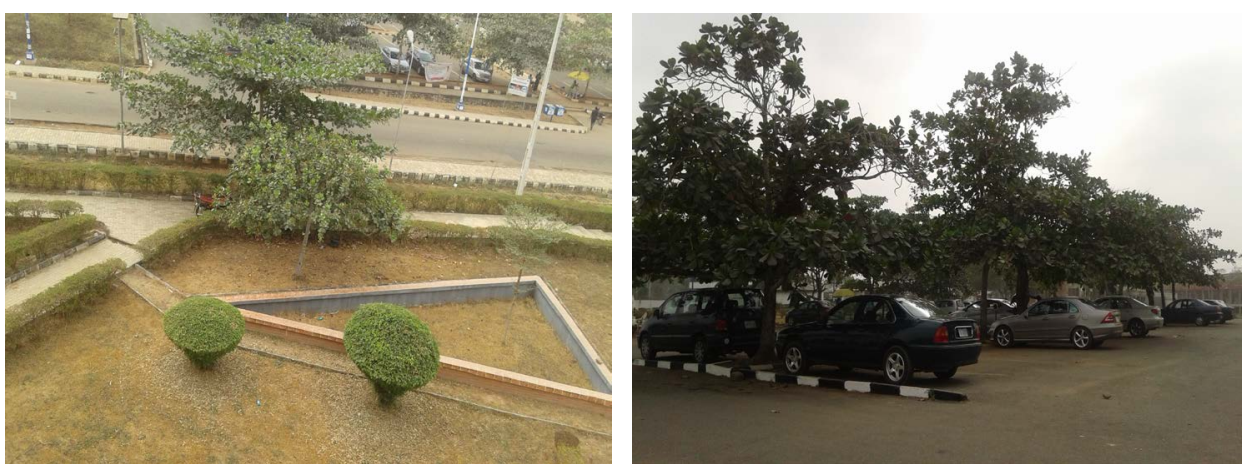

Plate 2. Landscape elements.

and planning of the institution. Plant materials of different kinds (color) should be adopted in landscaping of the campus environment in order to improve the aesthetic value.

The Planning and Horticulture Unit which is saddle with the responsibility of campus beautification should ensure the arrangement of landscape in line with the principles of landscape design and planning. Also there should be continuous and a wellstructured maintenance schedule of landscape elements of the University to sustain the beautification of the environment. Adoption of the use of durable and good quality elements of landscape such as sit outs, statue, fountain, flower pots, and so on would also improve the landscape outlook of the institution.

Trees of different species should be introduced at car parks, strategic and organized open spaces to control global warming by maintaining the amount of carbon (IV) oxide in the atmosphere and also serve as wind breakers. The introduction of ever-green lawn around buildings or structure on the University's campus would give aesthetic look to the campus and also help in preventing soil erosion which is a major problem confronting some areas of the campus. The University management needs to earmark enough funds to planning and training of staff in the horticulture units for landscape planning and environmental improvement including creation of formal and informal gathering areas, outdoor rooms with various spatial qualities, improvement in crosscampus pedestrian connectors and use of kerbs. All these will improve the landscape quality as the University ultimately achieves a sustainable campus environment.

\section{References}

[1] Garrett, E. (1964) Urban Landscape Design. McGraw Hill Publisher, New York.

[2] Smith, P.C. (1997) Reinventing the City. Sustainability and the Built Environment HKIA Journal First Quarter.

[3] Elf, D. (1996) Enhancing our Environment through Landscaping. VCE Publication, 429-721.

[4] Falade, J.B. (1998) Nigeria's Urban Open Space: An Inquiry into Their Evolution, Planning and Land Space Qualities. An Unpublished Ph.D. Thesis, Department of Architecture, University of Edinburgh, UK. 
[5] Nuttgens (1973) Concept of Landscaping. New York Academic Press, New York.

[6] Ibimilua, A.F. (2014) Key Issues on Landscape Planning in the Context of Environmental Sustainability. European Scientific Journal, 10, 143-156.

[7] Essaghah, A. (1997) Urban Planning Concepts, Standards and Symbols. Amfitop Books Nig. Ltd., Lagos.

[8] Wright, R.T. (2008) Environmental Science: Toward a Sustainable Future. PHI Learning, New Delhi.

[9] Fadamiro, J.A. (1998) Landscape Design and Environment. Adeyemo Publishing House, Akure.

[10] Mitchell, N.J. (2014) Conserving the Cultural Landscapes, University of Vermount, USA. Published as Part of Series Routledge Studies in Heritage, 2014.

[11] Elmond, J.B. (1975) Fundamental of Horticulture. Tata McGraw Hill Publishing Coy., New Delhi, 560.

[12] Hess, G.R. and Fischer, R.A. (2001) Communicating Clearly about Conservation Corridors. Landscape and Urban Planning, 55, 195-208. http://dx.doi.org/10.1016/S0169-2046(01)00155-4

[13] Adersson, E. and Bodin, O. (2009) Practical Tool for Landscape Planning; an Empirical Investigation of Network Based Model of Habitation Fragmentation. Echography, 32, 123 132.

[14] Morley, J. (2008) Basic Principles and Elements of Landscape Design. http://mkrittenhouse.com/us/basic-principles-and-elements-of-landscape-design

[15] Kadamu, D. and Pearlman, J. (2015) College Planning and Management, Space for Learning. https://webcpm.com/Articles/2015/09/21/Keys-to-Space-Management.aspx

[16] Forbes, S. and Kendle, T. (2013) Urban Nature Conservation; Landscape Management in Urban Area, London, UK. E and FN spon and Imprint of Thompson Professional, 2-6.

[17] Ogunsote, O.O., Adedeji, Y.M.D. and Prucnal-Ogunsote, B.P. (2011) Combating Environmental Degradation through Sustainable Landscaping in Emerging Mega Cities: A Case Study of Lagos, Nigeria. In: Cox, L., Ed., Proceedings of the 24th World Congress of Architecture "UIA2011 TOKYO", 25 September-October $12011,16-21$.

[18] Adedeji, Y.M.D., Aluko, O.O. and Ogunsote, O.O. (2010) Sustainable Landscaping and Green Housing in Tropical Climates: A Case Study of Akure, Nigeria. In: Olujimi, J.B., Bello, M.O., Ojo, E.B., Olotuah, A.O., Adebayo, M.A. and Omole, F.K., Eds., Proccedings of the 1 st International Conference of the School of Environmental Technology, Federal University of Technology, Akure, 25th-27th October 2010, 204-213.

[19] Ayeni, D.A. and Adedeji, Y.M.D. (2014) Controlling Urban Sprawl through Sustainable Landscaping in Nigeria. In: Fadamiro, J.A., Olujimi, J.A.B. and Okedele, O. Eds., Urban Environmental Sustainability: Livable Cities. Urban Design Research Team (UDRT), Department of Architecture, School of Environmental Technology, Federal University of Technology, Akure, Nigeria. 
Submit or recommend next manuscript to SCIRP and we will provide best service for you:

Accepting pre-submission inquiries through Email, Facebook, LinkedIn, Twitter, etc. A wide selection of journals (inclusive of 9 subjects, more than 200 journals)

Providing 24-hour high-quality service

User-friendly online submission system

Fair and swift peer-review system

Efficient typesetting and proofreading procedure

Display of the result of downloads and visits, as well as the number of cited articles

Maximum dissemination of your research work

Submit your manuscript at: http://papersubmission.scirp.org/

Or contact jep@scirp.org 